\title{
Student perceptions of group experience in online RN-to-BSN research course
}

\author{
Yeoun Soo Kim-Godwin ${ }^{* 1}$, Michael Martinez ${ }^{2}$ \\ ${ }^{1}$ University of North Carolina Wilmington, United States \\ ${ }^{2}$ Western Governors University, Salt Lake City, Utah, United States
}

Received: January 25, 2016

Accepted: March 29, 2016

Online Published: April 21, 2016

DOI: $10.5430 /$ jnep.v6n9p29

URL: http://dx.doi.org/10.5430/jnep.v6n9p29

\begin{abstract}
Objective: The overall aim of this pilot study was to explore students' perception of teaching, social, cognitive and learner presence within an RN to BSN asynchronous online nursing research course.

Methods: This descriptive correlational study used an online survey. Students' perceptions of learning effectiveness regarding group size and class size were assessed with the Revised Community of Inquiry (RCOI) questionnaire, which measures the dimensions of Teaching Presence (TP), Social Presence (SP), Cognitive Presence (CP), and Learner Presence (LP).

Results: Among the total of 121 enrolled RN to BSN students, 67 students participated in this study (response rate of 55.4\%). The findings of ANOVA indicated no statistical differences $(p>.05)$ in learning effectiveness among the different group sizes. However, groups with 5 members showed the highest scores of RCOI total $(M=149.5)$, TP $(M=36.82), S P(M=35.25)$, and CP $(\mathrm{M}=35.57)$. In contrast, groups with 3 members showed the lowest scores of RCOI total $(\mathrm{M}=137.19)$, TP $(\mathrm{M}=33.21)$, and CP $(M=32.32)$. Additionally, the findings of $t$-tests indicated no statistical differences $(p>.05)$ in learning effectiveness between the different class sizes.

Conclusions: The findings of the current study imply that learning effectiveness was not associated with group sizes or class sizes. However, the findings suggest that the use of group collaboration promotes teaching, social, cognitive, and learner presence.
\end{abstract}

Key Words: RN-to-BSN students, Online course, Group collaboration, Revised Community of Inquiry

\section{INTRODUCTION}

Registered nurses (RNs) required to return for their Bachelor of Science in Nursing (BSN) degree have added to the proliferation of online courses. ${ }^{[1]}$ According to the American Association of Colleges of Nursing (AACN), in 2015 there were $676 \mathrm{RN}$ to BSN programs in the United States with more than 400 of them offering programs at least partially online. ${ }^{[2]}$ Since many academic institutions and educators have identified the best online teaching and learning practices, online education methods have made remarkable advances. ${ }^{[3]}$
One of the challenges in online teaching is to enhance human interaction for student support, developing communication dialogue, and guiding socialization. ${ }^{[4]}$ In spite of the advantages of online education, isolation or lack of interaction and social presence was reported in literature as a major concern of both students and faculty in web-based courses. ${ }^{[5]}$ One major assertion in the criticism of asynchronous teaching is the lack of an instructor's physical presence. ${ }^{[6]}$ Students' learning expectations need to be considered as faculty members continue to provide quality online instruction. The paper

*Correspondence: Yeoun Soo Kim-Godwin; Email: kimy@uncw.edu; Address: Yeoun Soo Kim-Godwin, 601 South College Rd., Wilmington, NC 28403, School of Nursing, UNCW, United States.

Published by Sciedu Press 
reports the use of group discussion to promote active learning and writing practices for a writing intensive research course within an RN to BSN online program at a southeastern university in the United States. The overall aim of this pilot study is to explore students' perception of teaching, social, cognitive and learner presence, using the Revised Community of Inquiry (RCOI) questionnaire, within an RN to BSN asynchronous online nursing research course. Additionally, the study was to explore students' perceptions of their group work and peer-evaluation experiences.

\subsection{Literature review}

The literature focuses on identifying the most effective group discussion in relation to group configuration and class size in online classes.

\subsubsection{Group size and collaborative learning}

Online group discussions provide flexibility in terms of group size and dynamics. ${ }^{[4]}$ One of the significant factors in explaining the possible impact of active online learning is group size. ${ }^{[7]}$ Generally, many researchers prefer smaller groups because they make possible an expanded range of tasks and responsibilities for each member of a group. According to Gagne, Wager, Golas, and Keller, smaller groups also support active learning - enabling group members to work as active participants in the process of data gathering, organizing and synthesizing the data, and thereby establishing knowledge. ${ }^{[8]}$ However, in groups of smaller size, there is a greater potential for group conflicts to detract from the process of collaborative learning. For smaller groups, opportunities are enhanced to develop skills in communication and problem-solving. This is especially because smaller groups provide similar opportunities for leadership for all members. ${ }^{[4]}$ In the case of larger size groups, the factor of size can inhibit member participation-especially among those who are fearful of dissension, prefer to avoid deviance, or are simply less extroverted. ${ }^{[4]}$

\subsubsection{Class size and online learning}

Educators are also concerned about how the quality of education can be maintained when class size increases. Class size has traditionally been bound by the physical classroom space available, but web-based courses eliminate that limitation. ${ }^{[9]}$ In 2009, Burruss and colleagues analyzed data from undergraduate $(n=265)$ and graduate $(n=863)$ nursing students enrolled in online nursing courses. ${ }^{\text {[9] }}$ Variables in this study included active participation and learning, student-to-student interaction, faculty-to-student interaction and the level of connectedness students experienced when engaging in learning activities. The most significant finding was the different perceptions between undergraduate and graduate students on the effect class size had on fostering social presence. ${ }^{[9]}$ Koenig and colleagues examined class size preferences as 30 well as reasons behind these preferences among 162 college students and reported that students preferred smaller classes more for major-related courses than for general education and noninteresting required courses. ${ }^{[10]}$ However, in general, students did not have a very strong preference for smaller class sizes for these courses, when asked if they would prefer to enroll in the larger or smaller section of a course. ${ }^{[10]}$

Web-based courses allow the opportunity to offer larger classes, thus raising questions about how many students can enroll in one course while maintaining course quality. Depending on course content and structure, upper level courses may need smaller class sizes. ${ }^{[11]}$ Smaller class sizes tend to be associated with higher quality but a class size that is too small may produce an insufficient diversity of backgrounds, experiences, preexisting knowledge, and learning styles. ${ }^{[9]}$ However, Taft, Perkowski, and Martin reviewed 12 selected multidisciplinary research articles on determining optimal online class sizes and found no consensus regarding optimal class size in online courses. ${ }^{[1]}$ The authors addressed factors relevant to determining optimal class size from the three educational frameworks of Bloom's taxonomy, objectivist-constructive teaching strategies, and the Community of Inquiry (COI) model. The authors recommended large size classes ( $\geq 30$ students) for the courses mainly using objective teaching strategies with limited implementation of the COI model and lower levels of learning in Blooms' taxonomy (i.e., introductory biology). ${ }^{[11]}$ In contrast, small size classes ( $\leq 15$ students) are recommended for courses using constructive teaching strategies, full implementation of the COI model, and higher levels of learning in Blooms' taxonomy. ${ }^{[11]}$

To summarize, a review of the literature illustrated many examples of researchers suggesting appropriate group and class sizes for discourse-based online courses. However, less clear guidance was provided due to somewhat conflicting findings and the complex nature of online learning. The current understanding reflected in the literature is that the guidelines for determining class sizes for online, for-credit courses involves multiple factors (such as teaching frameworks, group dynamics, peer evaluation, and instructors' involvement). ${ }^{\text {[9-11] }}$ Therefore, a thorough analysis of effective class size in online learning is not complete until the students' perspective is considered.

\section{MeTHODS}

The descriptive correlational study aimed to explore students' perceptions of learning effectiveness regarding the different group and class size. Learning effectiveness was measured by the four dimensions of teaching, social, cognitive, and learner presence of the RCOI.

ISSN 1925-4040 E-ISSN 1925-4059 
Table 1. RCOI (Revised Community of Inquiry) Items and Open-ended Questions
Teaching Presence (8 items)
1. Communicating clearly important activity goals.
2. Providing clear instructions on how to participate in learning activities.
3. Communicating important due dates/time frames for learning activities.
4. Helping to keep course participants engaged and participating in productive dialogue.
5. Encouraging course participants to explore new concepts in the activities.
6. Reinforcing the development of a sense of community among course participants.
7. Providing useful illustrations that helped make the course content more understandable to me.
8. Clarifying explanations or other feedback that allowed me to better carry out the activities.

\section{Social Presence (8 items)}

1. Giving me a sense of belonging in the course.

2. Being able to form distinct impressions of some course participants.

3. Feeling of being comfortable conversing through the online medium.

4. Feeling of being comfortable participating in the course discussions.

5. Feeling of being comfortable interacting with other course participants.

6. Feeling of being comfortable disagreeing with other course participants while still maintaining a sense of trust.

7. Feeling that my point of view was acknowledged by other participants.

8. Helping me to develop a sense of collaboration.

\section{Cognitive Presence (8 items)}

1. Increasing my interest in course issues.

2. Feeling of being motivated to explore content related questions.

3. Utilizing a variety of information sources to explore problems.

4. Brainstorming and finding relevant information helped me resolve content related questions.

5. Combining new information helped me answer questions raised in course activities.

6. Helpful learning activities to construct explanations/solutions.

7. Helpful reflection on course content and discussions to understand fundamental concepts in this class.

8. Being able to apply the knowledge created in this course to my work or other non-class related activities.

\section{Learner Presence (9 items)}

1. Setting goals for myself in order to direct my activities in each study period when I studied for the activities.

2. Asking myself questions to make sure I know the assigned activities I have been working on.

3. Trying to change the way I studied in order to fit the activity requirements and the instructor's teaching style.

4. Working hard to get a good grade even when I was not interested in some topics.

5. Trying to think through a topic and decide what I am supposed to learn from it rather than just reading materials or following directions.

6. Thinking about the things I will need to do to learn before I began studying.

7. Trying to determine which concepts I didn't understand well when studying for the activities.

8. Stopping once in a while to go over what I have done when I was working on learning activities.

9. Feeling of being confident using the technologies associated with out-of-class activities in general.

\section{Open Ended Questions}

1. How did you feel throughout the group work experience in general?

2. What specific difficulties do you remember?

3. How did you feel about the experience of being a peer evaluator? Was it helpful?

The RCOI framework theorizes four elements that contribute to a successful learning environment: Cognitive Presence (CP), Social Presence (SP), Teaching Presence (TP), and Learner Presence (LP). Garrison, Anderson, and Archer proposed the Community of Inquiry (COI) framework, which is based on a model of critical thinking and practical inquiry. ${ }^{[12]}$ From a collaborative constructivist point of view, it represents online learning as supported by three presences: social presence, teaching presence, and cognitive presence. ${ }^{[13]}$ The framework hypothesizes online knowledge building as the outcome of collaborative work among active participants in learning communities reflecting instructional coordination appropriate to the online environments (teaching presence) and an encouraging collegial online setting (social presence) ${ }^{[13]}$ Although the COI has been one of the most commonly referenced means for researching formal higher- 
level online education, it has been criticized particularly due to the limited nature of a constructivist orientation, rather than an outcomes-based measure within an objectivist orientation. ${ }^{[14]}$ Shea and Bidjerano proposed a revised version of the COI (RCOI) framework that incorporated the effects of individual learner attributes on learning. ${ }^{[15]}$ The fourth construct, LP is characterized as a combination of self-efficacy and individual effort. According to Shea and Bidjerano, the combination of learning, teaching, and social presences predicted better than $75 \%$ of perceived cognitive presence in both blended and online learning environments. ${ }^{[15]}$

\subsection{Instrument}

The online survey questionnaires include demographic questions, the RCOI, and three open-ended questions. The RCOI instrument is a self-reporting, 37-item, 5-point Likert-scale questionnaire: 1 indicates strongly disagree; 2 , disagree; 3 , neutral; 4, agree; and 5, strongly agree. The RCOI questionnaire included the four sub-scales of TP (8 items), SP (8 items), CP (8 items), and LP (9 items). ${ }^{[16]}$ In addition, three open-ended questions were included to specifically solicit feedback about the students' group-work experiences. See Table 1 for a description of specific items in the RCOI and open-ended questions.

\subsection{Sample and procedure}

With approval from the institutional review board from a University, an online survey was administered to students in the courses at the end of the semester. Samples are RN-BSN students enrolled in the nursing research course in spring and summer 2015. In spring 2015, a total of 60 students were enrolled in three separate sections of nursing research $(21,24$, and 15 students respectively). Each section had a separate Blackboard course shell. In summer 2015, a total of 61 students enrolled in the nursing research course, and three sections of the course were merged into one section with one Blackboard shell. During both semesters, students were randomly assigned in groups of 3 to 5 to complete the group writing assignments; however, due to student withdrawals, 5 groups had 2 members. In addition, students who wanted to complete the assignments by him/herself, were allowed to do so independently.

The research course focuses on evidence-based practice and requires students to write six papers over the seven and a-half week period. Of these, $30 \%$ of writing assignments are group projects. As a group, students are required to complete four drafts weekly (5\% of the course grade for each draft, $20 \%$ total). Based on the faculty feedback, students opt to revise the drafts prior to the submission of their final paper (10\% of the course grade respectively). See Table 2 for a description of writing course assignments.

Table 2. Writing Course Assignments

\begin{tabular}{lll}
\hline $\begin{array}{l}\text { Assigned } \\
\text { Module }\end{array}$ & $\begin{array}{l}\text { Evidence Based Practice } \\
\text { Project }\end{array}$ & Grade \\
\hline Module 1 & Selection of the topic & NA (not graded) \\
Module 2 & Introduction draft & $5 \%$ \\
Module 4 & Validation draft & $5 \%$ \\
& Comparative Analysis & $5 \%$ \\
Module 5 & /Evaluation draft & $5 \%$ \\
Module 6 & Decision Making draft & $10 \%$ \\
\hline
\end{tabular}

All students were also required to participate in weekly online discussions with other group members. If they wished to work individually, they were to interact with other members and/or the Teaching Associate (TA) in designated discussion spaces. Students were required to post their primary response(s) by Wednesdays. After students posted their initial responses, group members were required to provide their peer feedback by Fridays using the guidelines provided in the course. After providing peer feedback, all group members worked together to complete a weekly group paper by Sundays (Modules 2, 4, 5, $6 \& 7$ ). The TA facilitated the weekly discussions, and accessed the discussion sites and provided feedback at least three times per week. He replied to the students' questions and prompted the direction of the paper if needed. Students' weekly discussion was graded by the TA ( $5 \%$ of the course grade). At the end of each module, the TA evaluated the students' participation and quality of the discussion and provided his feedback. The instructor (first author of the paper) and the TA (second author of the paper) discussed the progress of the students' work each week.

\subsection{Analysis}

Descriptive statistics were used to analyze the demographic characteristics of the respondents and to assess the degree of perceived learning effectiveness (Score of items in RCOI). Bivariate statistics ( $t$-tests, and analyses of variance [ANOVAs]) were used to compare the learning effectiveness between the different group sizes and class size. A $p$-value less than .05 (2 sided) was defined as statistically significant. The Statistical Package for the Social Science (SPSS) version 19 was used to analyze the quantitative data.

\section{RESULTS}

\subsection{Demographic characteristics}

Among the total of 121 enrolled students, 67 students participated in this study (response rate of 55.4\%). The respondents were overwhelmingly female $(n=62)$ and white $(n=56)$ with 6 African Americans, 1 Hispanic, and 3 Asians. Student ages ranged from 22 to 57 years with an average of 34.6. 
Prior educational backgrounds of the respondents included associate degree $(n=52)$, baccalaureate degree $(n=13)$, and master's degree $(n=2)$. The majority of students reported having considerable degree of computer expertise (19 being an expert, 40 intermediate, 7 novice, and 1 no experience).

\subsection{Learning outcomes (RCOI) and group size}

Students' perceptions of learning effectiveness regarding group size were assessed with the RCOI, which measures TP, SP, CP, and LP. Reliability scores for the total scale in the current study were 0.94 (RCOI), and each subscale was 0.94 (TP), 0.91 (SP), 0.95 (CP) and 0.65 (LP).

As shown in Table 3, groups are divided by size according to number (1-5). The findings of ANOVA indicated no statistical differences in learning effectiveness among the different group sizes. However, groups with 5 members showed the highest scores of RCOI total ( $\mathrm{M}=149.5)$, TP $(\mathrm{M}=36.82)$, SP $(M=35.25)$, and CP (35.57). In contrast, groups with 3 members showed the lowest scores of RCOI total ( $\mathrm{M}=$ 137.19), TP $(\mathrm{M}=33.21)$, and $\mathrm{CP}(\mathrm{M}=32.32)$.

Students who completed the project by him/herself also showed lower scores than students with 2,4 , or 5 members in RCOI total $(\mathrm{M}=139.6)$. They also had the lowest scores in SP $(M=31.36)$ and $L P(M=37.89)$ when compared to other students who worked in groups. Additional t-test revealed that students who completed the project independently showed lower scores in SP $(M=31.36)$ than students belonging to groups of 4 and $5(M=34.66, p=0.04)$. See Table 3 for comparison of RCOI total score and the subscale scores of TP, SP, CP, and LP by the size of groups.

Table 3. Learning Effectiveness by Group Size

\begin{tabular}{|c|c|c|c|c|c|c|}
\hline & \multicolumn{5}{|c|}{ Group Size } & \multirow{2}{*}{$F(p)$} \\
\hline & 1 & 2 & 3 & 4 & 5 & \\
\hline RCOI & 139.63 & 142.75 & 137.19 & 145.44 & 149.5 & $\begin{array}{l}1.31 \\
(0.277)\end{array}$ \\
\hline $\begin{array}{l}\text { Teaching } \\
\text { presence } \\
(\mathrm{TP})\end{array}$ & 35.22 & 36.5 & 33.21 & 34.90 & 36.82 & $\begin{array}{l}1.26 \\
(0.29)\end{array}$ \\
\hline $\begin{array}{l}\text { Social } \\
\text { presence } \\
\text { (SP) }\end{array}$ & 31.36 & 33.00 & 32.68 & 34.16 & 35.25 & $\begin{array}{l}1.33 \\
(0.26)\end{array}$ \\
\hline $\begin{array}{l}\text { Cognitive } \\
\text { presence } \\
\text { (CP) }\end{array}$ & 34.00 & 34.25 & 32.32 & 34.47 & 35.57 & $\begin{array}{l}1.08 \\
(0.37)\end{array}$ \\
\hline $\begin{array}{l}\text { Learner } \\
\text { Presence } \\
\text { (LP) }\end{array}$ & 37.89 & 39.00 & 38.69 & 40.25 & 40.07 & $\begin{array}{l}0.50 \\
(0.28)\end{array}$ \\
\hline $\begin{array}{l}\text { No of } \\
\text { respondents }\end{array}$ & 9 & 4 & 19 & 19 & 16 & 67 \\
\hline
\end{tabular}

Note. Revised Community of Inquiry (RCOI); Group size indicates the number of students per group; Numeric values indicate the mean scores of RCOI and subscales

Table 4. Comparison of Score of RCOI Total and Subscales between Small and Large Classes

\begin{tabular}{|c|c|c|c|}
\hline & $\begin{array}{l}\text { Small Size class } \\
(n=31)^{\dagger} \\
M( \pm S D)\end{array}$ & $\begin{array}{l}\text { Large Size Class } \\
(n=36)^{\ddagger} \\
M( \pm S D)\end{array}$ & $\begin{array}{l}T \text { test } \\
p \text { value }\end{array}$ \\
\hline ROCI Total & $139.1( \pm 16.6)$ & $147.2( \pm 14.5)$ & 0.50 \\
\hline Teaching Presence (TP) Total Score (8 items) & $34.4( \pm 5.7)$ & $35.5( \pm 4.3)$ & 0.89 \\
\hline TP Mean Score & 4.3 & 4.44 & \\
\hline $\begin{array}{l}\text { Item } 6 \text {. Reinforcing the development of a sense of community among } \\
\text { course participants.* }\end{array}$ & 4.13 & 4.53 & $0.02 *$ \\
\hline Social Presence (SP) Total Score (8 items) & $32.7( \pm 4.6)$ & $34.3( \pm 4.3)$ & 0.14 \\
\hline SP Mean Score & 4.09 & 4.29 & \\
\hline $\begin{array}{l}\text { Item 7. feeling that my point of view was acknowledged by other } \\
\text { participants.* }\end{array}$ & 4.1 & 4.42 & $0.05^{*}$ \\
\hline Cognitive Presence (CP) Total Score (8 items) & $33.2( \pm 5.2)$ & $34.7( \pm 4.0)$ & 1.00 \\
\hline CP Mean Score & 4.15 & 4.34 & \\
\hline Item 2. Feeling of being motivated to explore content related questions. * & 3.90 & 4.28 & $0.03 *$ \\
\hline Learner Presence Total Score (9 items) & $38.6( \pm 4.2)$ & $40.1( \pm 5.3)$ & 0.32 \\
\hline LP Mean Score & 4.29 & 4.46 & \\
\hline
\end{tabular}

Note. RCOI (Revised Community of Inquiry); 5 point Likert scale (1=strongly disagree with the statement \& $5=$ strongly agree with the statement); ${ }^{\dagger}$ Small size classes are classes of 21,24 , \& 15 students respectively. Total is not 60 because of missing value. ${ }^{\ddagger}$ Large class is a class of 61 students. Total is not 61 because of missing value.

\subsection{Learning outcomes (RCOI) and class size}

While the large class had 61 students, smaller size classes were divided into 3 classes of 21,24, and 15 students respectively. Students generally gave a high rating to their learning

Published by Sciedu Press outcomes of TP, SP, CP, and LP. In both groups, all students rated from 4.09 to 4.46, using a 5-point Likert scale, with 5 rating "strongly agree". As shown in Table 4, students in the large class generally showed higher scores of RCOI total 
$(\mathrm{M}=147.5)$ and all 4 subscales compared to students in the smaller classes.

The findings of $t$-tests indicated no statistical differences in learning effectiveness between the different group sizes. However, there were significant differences of learning outcomes for several items. The items received higher scores among the students that belonged to the large size class were: 1) "Instructor actions reinforced the development of a sense of community among course participants" (TP item 6) ( $p$ $=.02) ; 2$ ) "I felt that my point of view was acknowledged by other participants" (SP item 7) ( $p=.05)$; and 3) "I felt motivated to explore content related questions" (CP item 2) $(p=.03)$. Table 4 also lists these 3 items with $p$ value less than .5. See Table 4 for the total and mean score of RCOI, TP, SP, CP, and LP between small and large size classes.

\subsection{Students perceptions of group experience}

Table 5 lists the students' responses in regard to the group work experience. A total of 108 responses were generated (38 for Q1, 36 for Q2, and 34 for Q3).

When students were asked to share their group work experience $(\mathrm{Q} 1)$, the majority of the respondents stated that their group work experience was positive $(n=24)$. Most of these students feel that they were able to collaborate freely and communicate effectively with group members. For example, a student reported, "I felt empowered and my opinions were taken into consideration." However, several students $(n=6)$ did not show any strong preferences for the group work. In addition, considerable number of students $(\mathrm{n}=8)$ perceived their group experience negatively, attributing it to group members not putting in their fair share of work or group members not communicating well with each other.

Next, students were asked to share their specific difficulties during the group work $(\mathrm{Q} 2)$. The most commonly experienced barriers affecting group work were: timing, poor communication, different working styles, and lack of accountability of each member. Students provided suggestions on how to improve group work, such as placing more emphasis on individual accountability. For individual accountability, a student suggested that the instructor "reinforce frequent check-ins so the groups do not harbor resentment towards members."

Although peer evaluation was not a part of the course grading, students are required to provide peer evaluation during the writing process to complete the papers. When students were asked to describe their feelings about the experience of being a peer evaluator (Q3), two thirds of students (n $=24$ ) reported that they had positive learning experiences. Most students reported their peer evaluation experience to be helpful and beneficial to their learning. A student stated that "peer evaluation is important in the development of skills needed for my clinical practice area." Another student stated, "peer evaluations were very helpful because it helped me to reassess my thought process and think more critically." A student stated, "I felt different. It isn't the first time I have critiqued someone else's work, but it still felt different to me. It was helpful though, in terms of being able to see what I thought they needed to work on, so for myself, the next time I have a paper to write, I am looking for those things too to improve my work with." However, a few students $(\mathrm{n}=6)$ perceived their peer evaluation experience negatively; negative responses $(n=6)$ focused on students being uncomfortable in critiquing others' works.

Overall, their narrative statements suggested that group work-experience provided them with collaborative learning through peer-evaluation and self-reflection.

\section{Discussion}

The current study explored students' perspectives on learning effectiveness in regard to group collaboration relating to group and class size. Students generally perceived their group discussion experience favorably in regard to the RCOI (TP, SP, CP, and LP). Surprisingly, students who completed their assignment individually showed lower learning effectiveness (particularly, SP and LP), compared to the students who worked in groups. These findings reinforce the importance of group discussion. In a collaborative group, students' work together to create a product greater than any individual might achieve alone. Students do not necessarily do the same task, however, but rather may divide the work among themselves according to their preferences and abilities. The goal is not for the same learning to occur, but rather that meaningful learning occurs. ${ }^{[16]}$ According to Qui et al., it allows students to collectively develop common perspectives, bringing together a range of cognitive resources and learning experiences shared with the entire class. ${ }^{[4]}$ The findings also imply the significance of collaborative learning during group work. It also means that new insights may emerge during online discussions. ${ }^{[4]}$

Although no statistical significance was evident in the current study, the findings suggest a group of 5 may be the most effective group configuration, while a group of 3 may be the least effective. These findings are similar to the previous literature. Cohen stated that 4 or 5 is an optimal number for a group, as a group of 3 can exhibit special problems due to the potential isolation of a third member. ${ }^{[17]}$ AbuSeileek examined the effects of collaborative learning, small group size, and two different instructional modes among undergraduate students who took English as a Foreign Language (EFL). ${ }^{[18]}$ 
AbuSeileek found that a groups of 5-students showed significantly better performance over groups of 2 to 7 students. ${ }^{[18]}$ In contrast, Morrison argued that it is not uncommon for one or more group members who tend to be on the lazy side, not to contribute when there are more than 4 members in a group and considered that the ideal group size for online is 3 or 4 group members. ${ }^{[19]}$

Table 5. Students Perceptions of Group Experience: Narrative Statements

\begin{tabular}{|c|c|c|c|}
\hline & Perceptions & Description & $\mathbf{N}$ \\
\hline \multirow{8}{*}{$\begin{array}{l}\text { Open-ended Q1 } \\
\text { Group Work Experience - } \\
\text { favorable } \\
(\mathrm{n}=24)\end{array}$} & \multirow{3}{*}{$\begin{array}{l}\text { Positive Group Collaboration } \\
(\mathrm{n}=11)(29 \%)\end{array}$} & Worked well together & 8 \\
\hline & & Engaged & 1 \\
\hline & & Shared tasks & 2 \\
\hline & \multirow{3}{*}{ Positive Group Work Outcome $(n=5)(13 \%)$} & Improved group skills & 1 \\
\hline & & Empowered/confident & 3 \\
\hline & & Improved interaction & 1 \\
\hline & \multirow{2}{*}{ Positive Emotions (n=8) (21\%) } & Felt good/enjoyed & 5 \\
\hline & & Felt positive learning experience & 3 \\
\hline \multirow{5}{*}{$\begin{array}{l}\text { Open-ended Q1 } \\
\text { Group Work Experience - } \\
\text { unfavorable and neutral } \\
(n=14)\end{array}$} & \multirow{4}{*}{ Negative Group Collaboration (n=8) (21\%) } & Was challenging & 1 \\
\hline & & Unequal contribution & 5 \\
\hline & & Resentment against others & 1 \\
\hline & & Conflict due to individual difference & 1 \\
\hline & Neutral $(n=6)(16 \%)$ & OK/fine & 6 \\
\hline \multirow{13}{*}{$\begin{array}{l}\text { Open-ended Q2 } \\
\text { Barriers to Group Work } \\
(\mathrm{n}=36)\end{array}$} & \multirow{3}{*}{ Timing (n=8) (22\%) } & Different work schedule & 6 \\
\hline & & Difficulty in beginning stage & 2 \\
\hline & & Lack of communication & 3 \\
\hline & \multirow[t]{2}{*}{ Communication $(\mathrm{n}=8)(22 \%)$} & Unclear Instruction (by instructor) & 3 \\
\hline & & Waiting other members’ feedback & 2 \\
\hline & \multirow{3}{*}{$\begin{array}{l}\text { Working Style }(n=6) \\
(17 \%)\end{array}$} & Different Style/approach & 2 \\
\hline & & Domineering member & 1 \\
\hline & & Unequal contribution & 3 \\
\hline & \multirow{3}{*}{$\begin{array}{l}\text { Accountability }(\mathrm{n}=8) \\
(22 \%)\end{array}$} & Procrastination of some member & 3 \\
\hline & & Slackers & 2 \\
\hline & & Member accountability & 3 \\
\hline & \multirow{2}{*}{ None or minimal (n=6) (17\%) } & Minimal & 2 \\
\hline & & None (N/A) & 4 \\
\hline \multirow{12}{*}{$\begin{array}{l}\text { Open-ended Q3 } \\
\text { Group Work Experience - } \\
\text { Peer Evaluation }(n=34)\end{array}$} & \multirow{5}{*}{$\begin{array}{l}\text { Positive } \\
(n=24)(67 \%)\end{array}$} & (very) helpful & 16 \\
\hline & & (great) learning experience & 5 \\
\hline & & Better self-evaluation & 1 \\
\hline & & Important skill development & 1 \\
\hline & & Improvement of writing & 1 \\
\hline & \multirow{6}{*}{ Negative (n=6) (18\%) } & Not helpful & 1 \\
\hline & & Not comfortable & 1 \\
\hline & & Hard to evaluate & 1 \\
\hline & & Opinion (not evaluation) & 1 \\
\hline & & Lack of confidence & 1 \\
\hline & & Responsibility of instructor (not students) & 1 \\
\hline & Neutral (4) (12\%) & Don’t know or N/A & 4 \\
\hline
\end{tabular}

As stated earlier, students who wanted to complete the assignments by him/herself, were allowed to do so independently. However, the students who completed the project by $\mathrm{him} /$ herself showed lower scores than students with 2, 4, or 5 members in RCOI total and SP (Social Presence). These

findings may imply the benefits of group work. ${ }^{[20]}$ Although online group work faces many challenges, group projects may enable students to develop abilities and skills of both individual work and collaborate efforts. ${ }^{[20]}$ Collaborative learning especially has been reported to be a useful tool for 
online learning where group members tend to lack social support and interaction, as found in traditional classroombased instruction. ${ }^{[4]}$ One of major challenges of group work is keeping students motivated and coping with negative emotions in the group work process. ${ }^{[21]}$ Smith et al. found that students held a more negative attitude toward online group work than face-to-face group work (e.g., less motivated to engage in group work). ${ }^{[22]}$

The findings of the current study indicated no statistical differences in the learning outcomes between small and large classes. Rather, students in a large class showed higher scores in RCOI. Previous literature regarding the optimal class size shows little inconsistency. Burruss et al. stated that large classes in their study were associated with less satisfaction and less learning compared to smaller classes. ${ }^{[9]}$ In addition, an overly large class may contain greater individual variance and relationship complexity, leading to greater risk of conflict. ${ }^{[11]}$ However, a recent national study shows that the persistence of students, student grades, or the likelihood of students to enroll in future courses remain unaffected by increases in online class size. ${ }^{[23]}$ These researchers were able to track outcomes for more than 100,000 students in nearly 4,000 sections of 102 different courses (undergraduate and graduate). Talf et al. argued that faculty teaching in "objective test-based courses" can effectively teach very large numbers online and students will generally learn equally well if they are in a class of 5 or 500 if faculty uses a predominantly objective approach. ${ }^{[11]}$ However, based on the contents of the course and teaching orientation, the optimal class size would be variable. For example, graduate research methods and design could demand greater faculty-student interaction and more teaching-intense elements, therefore class size should be small. ${ }^{[11]}$

The findings of this study also imply that nurse educators need to plan to enhance cohesive group work experience when teaching large-size online classes. Students' narrative statements suggest that failure to consider group cohesion in relation to group or class size can lead to stressful or unsuccessful online discussion. To function effectively, a group has to cohere, which leads sense of belonging among members, while promoting a positive atmosphere. ${ }^{[4]} \mathrm{Xu}, \mathrm{Du}$, and Fan who analyzed the data from 298 students (86 groups) in the United States, reported that group work was positively associated with feedback, peer- and learning-oriented reasons, help seeking, and the number of online courses. ${ }^{[21]}$

Since the best predictor of positive student learning is instructor-student interaction, ${ }^{[11]}$ instructor/teaching assistant's frequent feedback is essential. Taft et al. stated that a larger class $(\geq 30)$ can be managed by breaking into smaller discussion sections with an instructor or teaching assistant assigned to each small group and having an effect smaller group size. ${ }^{[11]}$

Finally, the findings indicated that students perceived peer interaction and evaluation during the group discussion to be highly effective for their learning. They also experienced improved social and learner presence. Such student interactions enhance a common effort to realize goals as students learn to facilitate and promote each other's best efforts. Johnson and Johnson provided a new review of the evidence that has been produced on collaborative learning, along with fresh perspective on accountability and student interdependence, but also supported the promotion of student interactions. ${ }^{[24]}$ Studentto student interaction has been reported as the second best predictor of student learning ${ }^{[11]}$ In conclusion, the findings suggest that group assignment may be more beneficial than independent assignment, and an ideal group size would be 4 or 5-a size large enough to increase interaction. In addition, the findings suggest that class size may not be an important factor in learning for online classes.

\subsection{Limitations}

There are several limitations to this study, including the use of a small convenience sample. In addition, the assessments in this study were students' perceptions and not direct measurements of learning outcomes. Further study is needed to determine factors that correlate to actual learning outcomes and factors affecting group and class sizes. The strength of the study was the use of RCOI which address the essential predictors of effective student learning. ${ }^{[11]}$ However, the current study did not address the dimensions of course design which are also predictors of student learning. ${ }^{[3]}$ Additional factors inducing optimal group collaboration could be considered.

\subsection{Conclusions}

The findings of the current study imply that class size may not influence learning outcomes when utilizing group collaborations. Nurse educators who are teaching online classes are challenged with finding ways to facilitate effective student learning. RCOI model in online education assumes that the instructor's role is critical in potentiating student learning. [11] The findings of the current study provide some insights for nurse educators using group collaboration to enhance active learning and writing skills. Findings of the current study also suggest that integration of peer evaluation in group discussion would be considered an effective method for online teaching.

\section{CONFlicts OF InTEREST Disclosure}

The authors declare that there is no conflict of interest. 


\section{REFERENCES}

[1] Matthias A, Kim-Godwin YS. RN-BSN Students' Perceptions of the Differences in Practice of the ADN- and BSN-Prepared RN. Nurs Edu. 2016. http://journals.lww.com/nurseeducatoronli ne/Abstract/publishahead/RN_BSN_Students__Percepti ons_of_the_Differences_in.99845.aspx, Published Feb 9, 2016, Accessed March 15, 2016

[2] American Association of Colleges of Nursing (AACN). Degree completion programs for registered nurses. Washington, D. C. http://www.aacn.nche.edu/media-relations/f act-sheets/degree-completion-programs. 2015. Published March 16, 2015, Accessed March 17, 2015

[3] Outlaw V, Rice M. Best Practices: Implementing an Online Course Development \& Delivery Model. Online Journal of Distance Learning Administration. 2015; 15(3): e1-e15. http://www . westga.e $\mathrm{du} /$ distance/ojdla/fall183/outlaw_rice183.html

[4] Qiu M, Hewitt J, Brett C. Influence of group configuration on online discourse writing. Comput Educ. 2014; 71: 289-302. http: //dx.doi.org/10.1016/j.compedu. 2013.09.010

[5] Plante K, Asselin ME. Best Practices for Creating Social Presence and Caring Behaviors Online. Nurs Educ Persp. 2014; 35(4): 219-223. PMid:25158415. http://dx.doi .org/10.5480/13-1094.1

[6] Gazza EA, Hunker DF. Facilitating student retention in online graduate nursing education programs: A review of the literature. Nurs Edu Today. 2014; 34(7): 1125-1129. http://dx.doi.org/10.1016/j .nedt.2014.01.010 http://www.sciencedirect.com/scie nce/article/pii/S0260691714000343

[7] Qiu M, Hewitt J, Brett C. Online class size, note reading, note writing and collaborative discourse. International Journal of ComputerSupported Collaborative Learning. 2012; 7(3): 423-442. http: //dx.doi.org/10.1007/s11412-012-9151-2

[8] Gagne RM, Wager WW, Golas KC, et al. Principles of Instructional Design. 5th ed. Belmont, CA: Thomson/Wadsworth; 2005.

[9] Burruss NM, Billings DM, Brownrigg V, et al. Class size as related to the use of technology, educational practices, and outcomes in web-based nursing courses. J Prof Nurs. 2009; 25(1): 3341. PMid:19161961. http://dx.doi.org/10.1016/j.profnur s. 2008.06.002

[10] Koenig LB, Gray M, Lewis S, et al. Student Preferences for Small and Large Class Sizes International Journal of Humanities and Social Science. 2015; 5(1): 20-29. http://www. ijhssnet.com/journ als/Vol_5_No_1_January_2015/2.pdf

[11] Taft SH, Perkowski T, Martin LS. A Framework for Evaluating Class Size in Online Education. Quart Rev of Dis Educ. 2011; 12(3): 181-197. http://digitalcommons.kent.edu/cgi/vi ewcontent. cgi ?article=1000\&context=nurspubs Published 2011, Accessed March 17, 2016.

[12] Garrison DR, Anderson T, Archer W. Critical inquiry in a textbased environment: Computer conferencing in higher education. The Internet and Higher Education. 1999; 2(2-3): 87-105. http://dx.doi.org/10.1016/S1096-7516(00)00016-6. Accessed http://www.sciencedirect.com/science/article/ pii/S1096751600000166
[13] Swan K, Matthews D, Bogle L, et al. Linking online course design and implementation to learning outcomes: a design experiment. The Internet and Higher Education. 2012; 15(2): 81-88. http://dx.doi.org/10.1016/j.iheduc. 2011.07.002

[14] Shea P, Hayes S, Smith SU, et al. Learning presence: additional research on a new conceptual element within the Community of Inquiry (CoI) framework. The Internet and Higher Education. 2012; 15(2): 89-95. http://dx.doi.org/10.1016/j.iheduc. 2011 .08 .002

[15] Shea P, Bidjerano T. Learning presence: Towards a theory of selfefficacy, self-regulation, and the development of a communities of inquiry in online and blended learning environments. Comp in Educ. 2010; 55: 1721-1731. http://dx.doi.org/10.1016/j.compe du.2010.07.017. Accessed http://www.sciencedirect.com/ science/article/pii/S1096751611000522

[16] Major CH. Choosing the Best Approach for Small Group Work Faculty Focus. 2015, http://www.facultyfocus.com/artic les/effective-teaching-strategies/choosing-the-bes t-approach-for-small-group-work/ Published September 21, 2015, Accessed March 18, 2016

[17] Cohen EG. Restructuring the classroom: conditions for productive small groups. Rev Educ Res. 1994; 64(1): 1-35. http://dx.doi.o $\mathrm{rg} / 10.3102 / 00346543064001001$

[18] AbuSeileek AF. The effect of computer-assisted cooperative learning methods and group size on the EFL learners' achievement in communication skills. Comput Educ. 2012; 58(1): 231-239. http://dx.doi.org/10.1016/j.compedu . 2011.07.011

[19] Morrison D. Strategies for effective group work in the Online Class Online Learning Insights. https://onlinelearninginsights .wordpress . com/2012/03/27/strategies-for-effective -group-work-in-the-online-class/ Published March 27, 2012, Accessed March 18, 2016.

[20] Caruso HM, Wooley AW. Harnessing the power of emergent interdependence to promote diverse team collaboration. Diversity and Groups. 2008; 11: 245-266. http://www.emeraldinsight.com /doi/abs/10.1016/S1534-0856\%2808\%2911011-8 Accessed March 16, 2016

[21] Xu J, Du J, Fan X. Students' Group work Management in Online Collaborative Learning Environments. Educ Tec \& Soc. 2015; 18(2): 195-205. http://www.jstor.org/stable/jeductechso ci.18.2.195 Accessed March 17. 2016

[22] Smith GG, Sorensen C, Gump A, et al. Overcoming student resistance to group work: Online versus face-to-face. Internet and Higher Education. 2011; 14: 121-128. http://dx.doi.org/10.1016/j .iheduc.2010.09.005 http://www.sciencedirect.com/sc ience/article/pii/S1096751610000709

[23] Bettinger E, Doss C, Loeb S, et al. Panel Paper: Virtually large: The effects of class size in online college courses. Paper presented at: 2014 APPAM Fall Research Conference; November 2014; Albuquerque, New Mexico.

[24] Johnson DW, Johnson RT. An educational psychology success story: social interdependence theory and cooperative learning. Educ Res. 2009; 368(5): 365-379. 